Research Article

\title{
Measurement and Analysis of the Competitiveness of China Commercial Bank's Loan Market
}

\author{
Tianming Cai $(\mathbb{D}$ \\ College of Finance \& Information, Ningbo University of Finance \& Economics, Ningbo 315175, China \\ Correspondence should be addressed to Tianming Cai; nbctm@163.com
}

Received 24 June 2020; Revised 9 July 2020; Accepted 16 July 2020; Published 10 August 2020

Guest Editor: Miaojuan Peng

Copyright (c) 2020 Tianming Cai. This is an open access article distributed under the Creative Commons Attribution License, which permits unrestricted use, distribution, and reproduction in any medium, provided the original work is properly cited.

China's economy presents a new normal of speed changes, structural optimization, and power conversion. Deepening supply-side reforms and controlling financial risks are two prominent themes of current economic work. With the economic growth slowing down and the financing environment tightening, the credit risk of the banking industry is being exposed more quickly. This article uses a structured method and an unstructured method to measure the competitiveness of China commercial bank credit market. The structured method uses the HHI (Herfindahl-Hirschman Index), and the unstructured method uses the Lerner Index. This article compares the sample banks' 2008-2015 industry loan total HHI and Lerner Index. The results of HHI and Lerner Index are basically the same, which indicate that the competitiveness of the China commercial bank credit market is generally at a low level. However, the Lerner Index has a clear upward trend after 2014, which indicates the possibility of increased competition in the credit market.

\section{Introduction}

The Chinese banking industry has been receiving great attention from the media in recent years, and there have been numerous reports of banks making high profits. This situation has triggered a lot of public criticism of the Chinese banking industry. People often question that lack of competition is the reason why banks make high profits. However, according to official statistics, the competitiveness of the Chinese banking industry is gradually increasing. On the one hand, judging from the proportion of nonstate-owned capital in Chinese commercial banks, the 2014 annual report of the China Banking Regulatory Commission showed that some small- and medium-sized commercial banks are 100\% private capital. Private capital of rural cooperative financial institutions nationwide accounts for over $90 \%$, and private capital of village and town banks accounts for over $72 \%$. On the other hand, from the perspective of the concentration of China's banking industry, the data of the main regulatory indicators for the third quarter of 2017 released by the China Securities Regulatory Commission show that the proportion of the total assets of the top five banks in China in the total assets of the banking industry decreased from 63\% in 1989 to $37.3 \%$ in 2017; this market concentration is lower than that of the top 10 developed countries such as the United States, Japan, Germany, and France, and other BRICS countries except India. However, there are still critics who believe that the increase in the shareholding of private capital and the decline in the concentration of the banking industry are not sufficient to deny the monopoly of state-owned banks. As far as the control is concerned, the dominant position of stateowned capital allows large banks to reach "unanimous action" on major issues, thereby forming a de facto monopoly in tacit agreement. The above debate on whether to monopolize involves an important empirical issue in the banking industry organization, namely, the measurement of the degree of competition in the banking industry.

According to the existing literature, there are two main methods for measuring the market competitiveness of the banking industry: the structural method and the nonstructural method. The Herfindahl-Hirschman Index (HHI) of the SCP model and efficiency hypothesis are the two most common denormalized structural methods for measuring the impact of centralization on competitiveness. The 
structural method index only considers external market structural factors such as the number and size of banks and cannot accurately measure the degree of competition in the banking market. Some economists have proved that there is no strict one-to-one correspondence between industry structure and competition, and unstructured laws have emerged. The unstructured method internalizes the market structure and measures the competitive behavior of manufacturers in the market by estimating the degree of deviation of the competitive price. The model test results are more accurate. The most used unstructured models are the Panzar and Rosse model [1, 2] and Lerner Index. The measurement of competition under the unstructured method emphasizes the analysis of the competitive behavior of banks, rather than using external information about market structure.

HHI is one of the better indicators for measuring the concentration of the industrial market and is the indicator most used by the economics community and government regulatory agencies. The theoretical basis of HHI actually derives from Bain's structure-conduct-performance theory. Bain's theory of industrial organization refers to the fact that the market structure affects the behavior of enterprises and ultimately determines the efficiency of market resource allocation (performance). With the concentration of market share, manufacturers will tend to adopt mutual collusion strategies, and the final price will deviate from the price of a completely competitive market. Manufacturers in a perfectly competitive market have no pricing power over the products they produce, and they are the recipients of market prices. Therefore, from the perspective of social welfare, perfect competition is the most ideal market structure. Any form of manufacturer monopoly and the resulting price higher than the monopoly price means a certain degree of consumer social welfare loss.

The Lerner Index originated from the models of Bresnahan $[3,4]$. It is based on the assumption that manufacturers pursue profit maximization and determines the degree of industry competition by estimating the degree of deviation between price and marginal cost. It is a nonstructural analysis method commonly used to judge the degree of industry competition. Shaffer first applied this method to the banking industry. The results of using industry time-series data show that the US and Canadian banking industries are in a state of perfect competition [5]. On this basis, Angelini and Cetorelli used panel data to develop a method that can estimate the Lerner Index over the sample period and applied it to the Italian banking industry [6]. Yang and Zhong studied the relationship between concentration, competition, and bank risk in China's banking industry [7]. The results show that the concentration and competitiveness of China's banking industry are significantly positively correlated with bank risk.

The HHI measurement is widely used and can reflect the bank's market structure, that is, whether it has a degree of monopoly. However, due to the difference in the probability of individual default in the credit portfolio sample, sometimes the results of the HHI measurement risk are not very accurate. Based on the concentration- vulnerability hypothesis, the degree of bank competition can be used for an effective intermediary variables of bank concentration affecting bank risk [8], and the Lerner Index used for the measurement accuracy can reflect the market structure of the banking industry. This article compares HHI measurement with Lerner Index measurement and measures the credit concentration risk of China's banking industry from two perspectives: structured and unstructured.

\section{Measurement and Analysis of the Risk of Concentration of Credit Loans in Industries Using the HHI}

2.1. Introduction to HHI. The HHI was originally a comprehensive index used to measure industry concentration. It measures the degree of market share concentration by measuring the sum of squares of the industry's total revenue or total asset percentage of the competitors in the industry, or to reflect the dispersion of the manufacturer's scale. HHI is also one of the better indicators for measuring bank concentration risk. It is the measurement method used by the economics community and government regulatory agencies, in which calculation equation is

$$
\mathrm{HHI}=\sum_{i=1}^{n}\left(\frac{X_{i}}{X}\right)^{2}=\sum_{i=1}^{n} S_{i}^{2} .
$$

Among them, $X$ represents the total scale of bank credit, $X_{i}$ represents the scale of bank credit, $S_{i}$ represents the share of the first bank credit line, and $n$ represents the total number of banks in the region. The HHI value is generally between 0 and 1 , but the banking system usually indicates that the method is to multiply its value by 100 or 10000 to enlarge it. In this paper, the HHI value is defined between 0 and 10000. The US Department of Justice uses the HHI value to evaluate indicators of the industrial market structure and sets the following standards (Table 1). In this paper, the degree of concentration risk is measured by the degree of competition of banks, that is, the gradient of oligopoly and competition. The higher the value, the higher the concentration risk, and the smaller the value, the lower the concentration risk.

According to the needs of the analysis, this paper uses all the Chinese commercial banks, namely, state-owned commercial banks, joint-stock commercial banks, city commercial banks, the total loans of local and foreign currency companies, and the total loans of local and foreign currency companies in all industries (corporate loans excluding overseas branches of commercial banks) when studying the overall concentration risk of the Chinese banking industry. When categorizing and identifying the concentration risks in the banking industry, the $\mathrm{HHI}$ is calculated using corporate loans from various commercial banks, banks are divided into different categories, and the HHI of different types of banks is compiled by weighting the proportion of assets. The equation for calculating the credit concentration risk index of type $m$ commercial bank is 
TABLE 1: Market structure classification based on the HHI value.

\begin{tabular}{|c|c|c|c|c|c|c|}
\hline \multirow[b]{2}{*}{$\begin{array}{l}\text { Market } \\
\text { structure }\end{array}$} & \multicolumn{4}{|c|}{ Oligopoly } & \multicolumn{2}{|c|}{ Competitive } \\
\hline & $\begin{array}{l}\text { High oligopoly } \\
\text { type I }\end{array}$ & $\begin{array}{l}\text { High oligopoly type } \\
\text { II }\end{array}$ & $\begin{array}{c}\text { Low oligopoly } \\
\text { type I }\end{array}$ & $\begin{array}{l}\text { Low oligopoly type } \\
\text { II }\end{array}$ & $\begin{array}{c}\text { Competitive type } \\
\text { I }\end{array}$ & $\begin{array}{c}\text { Competitive type } \\
\text { II }\end{array}$ \\
\hline HHI value & {$[3000,10000)$} & {$[1800,3000)$} & {$[1400,1800)$} & {$[1000,1400)$} & {$[500,1000)$} & $(0,500)$ \\
\hline
\end{tabular}

$$
\mathrm{HHI}_{m}=\sum_{j=1}^{n}\left(\frac{\mathrm{HHI}_{m, j} X_{m, j}}{\sum_{j=1}^{n} X_{m, j}}\right) .
$$

Among them, $X_{m, j}$ is the credit loan amount of type $m$ commercial bank $j, \sum_{j=1}^{n} X_{m, j}$ is the total credit loan amount of type $m$ commercial bank, $X_{m, j} / \sum_{j=1}^{n} X_{m, j}$ is the proportion of commercial bank $j$ in the total credit loan of type $m$ commercial bank, and $\mathrm{HHI}_{m, j}$ is the HHI of type $m$ commercial bank $j$.

2.2. Description of the Data. This article is limited to the availability of banking data. When studying the concentration risks of China's banking industry, the banks used only include commercial banks, namely, state-owned commercial banks, joint-stock commercial banks, urban commercial banks, rural commercial banks, foreign-funded banks, and no policy bank. The data comes from the annual report of the China Banking Regulatory Commission over the years, and the data is from 2008 to 2015 for the domestic and foreign currency company credit loans of Chinese commercial banks.

In this paper, when studying the concentration risk of the Chinese banking industry, the industry concentration is defined as local and foreign currency corporate loans operated and managed by domestic branches of Chinese commercial banks, excluding loans from overseas branches of various commercial banks.

When studying the concentration risk of China's banking industry, this paper defines the industry concentration as only including credit assets, excluding off-balance sheet assets and emerging off-balance sheet assets such as asset management and trust financing in recent years. The concentration data by industry in the annual reports disclosed by the China Banking Regulatory Commission and the sample banks only include credit assets.

In this paper, when comparing the concentration risks of China's banking industry, according to the quality of information disclosure of each commercial bank, 25 commercial banks are selected as the sample. The sample banks include Industrial And Commercial Bank Of China (ICBC), Agricultural Bank Of China (ABC), Bank of China (BOC), China Construction Bank (CCB), Bank of Communications (BoCom), 5 state-owned commercial banks. China CITIC Bank (CNCB), China Everbright Bank (CEB), China Merchants Bank (CMBC), Shanghai Pudong Development Bank (SPDB), China Minsheng Bank (CMBC), China Industrial Bank (CIB), Shenzhen Ping An Bank (SZPAB), Huaxia Bank (HXB), Guangdong Development Bank (CGB), Hengfeng Bank (EGB), China Zheshang Bank (CZB), China Bohai Bank (CBHB), 12 joint-stock commercial banks. Bank of
Beijing (BBJ), Bank of Shanghai (BOS), Bank of Tianjin (BTJ), Bank of Nanjing (BNJ), Huishang Bank (HSCB), Bank of Hangzhou (HZCB), Bank of Ningbo (NBCB), Bank of Wenzhou (WZCB), and 8 city commercial banks. The sample coverage of city commercial banks is relatively small, which is mainly limited by the disclosure level of city commercial banks on the risk concentration information of industry credit concentration. However, the above 8 sample banks are relatively large in scale of assets of Chinese city commercial banks, and their risk management level is relatively good and information disclosure is relatively adequate. From the analysis conclusions, the selection of these 8 samples has good representativeness. The data comes from the financial annual report publicly disclosed on the website of the sample bank. The data comes from the financial annual report publicly disclosed on the website of the sample bank. The data caliber is the local and foreign currency company credits of the sample commercial bank from 2008 to 2015 .

The data period studied in this paper selects the semiannual credit concentration risk data of commercial banks from 2008 to 2015. The choice of time period is, on the one hand, considering the reform of the state-owned commercial banks' shareholding system, which has a greater impact on the analysis of credit concentration risks. On the other hand, some small banks' information disclosure data can only be traced back to 2006 .

In the course of the research, this article encountered the lack of information on the credit concentration risk in the individual semiannual reports of Agricultural Bank of China, China Everbright Bank, and some city commercial banks. This article believes that a bank's industry credit concentration risk is unlikely to mutate within half a year, mainly because the bank's risk appetite determines the credit policy of the year, which industries enter and which industries exit, and the whole industry implements them. Therefore, the concentration of credit risk at the end of the year reflects the direction of the adjustment of the credit policy at the beginning of the year. In theory, it can be considered that the industry's concentration of credit risk in the half a year will adjust toward the end of the year as time progresses. Therefore, for the lack of credit concentration risk data in the semiannual report, this article uses linear interpolation and directly uses the simple average method at the beginning and end of the year to smooth.

2.3. Analysis of Measurement Results. In order to reflect the overall concentration risk situation of China's banking industry, this paper calculates the concentration risk index and draws a line chart of the sample bank's overall concentration risk after averaging the total loans of various types of 
commercial banks from December 2009 to December 2015 (Figure 1).

From Figure 1, the average credit loan concentration risk of various types of banks shows a relatively obvious upward trend. Among them, the concentration risk of state-owned commercial banks has the largest growth rate, followed by joint-stock commercial banks, and the smallest is city commercial banks. This conclusion is inconsistent with the statistics of various banks. This is mainly based on the size of the bank. Subsequently, the total data of the total loans of 25 sample banks from December 2009 to December 2015 were calculated, the HHI of the concentration risk of the banking industry was calculated, and a line chart was drawn (Figure 2).

It can be seen from Figure 2 that the HHI $* 10000$ index of the total concentration risk of 25 sample banks varies between 1160-1275, and the range of change is not particularly large. From this, it can be concluded that the overall structure of China's banking industry credit loan market is low Oligopoly type II, and concentration risk is at the low level. This shows that the credit portfolio of the Chinese banking industry is balanced and reasonable. The linear downward trend of concentration is obvious. This shows that the credit of China's banking industry is becoming more and more reasonable and competitive, and the risk of credit concentration is approaching the competitive risk space.

In order to illustrate the concentration risk among stateowned, joint-stock, and urban banks, this paper calculates the HHI of various banks based on the total credit loan data of three types of commercial banks and draws an index multiline line chart (Figure 3).

It can be seen from Figure 3 that there are certain differences in the $\mathrm{HHI} * 10000$ index of the concentration risk of total credit loans of the three types of banks. The concentration risk of urban commercial banks and joint-stock commercial banks has a clear downward trend. The concentration risk of state-owned commercial banks increased significantly from December 2009 to December 2014, after 2014 has a downward trend. The values of state-owned commercial banks and city commercial banks in December 2014 and December 2015 are very close, showing a roughly uniform concentration risk situation. The concentration risk of urban commercial banks is the highest, followed by stateowned commercial banks, and the lowest is joint-stock commercial banks.

Based on the data of total manufacturing loans of the above 25 commercial banks from December 2008 to December 2015, this paper draws a distribution map of the credit amount of each bank (Figure 4).

From Figure 4, it can be seen that the total credit loans of the manufacturing industry gradually increased from 2008 to 2014 and declined slightly in 2015. Judging from the distribution of total loans over the years, state-owned commercial banks account for a relatively large proportion. The top four are always Industrial and Commercial Bank of China, Agricultural Bank of China, Bank of China, and China Construction Bank. Table 2 is the proportion of various types of bank loans in the past years. From Table 2, it can be clearly seen that the four state-owned commercial

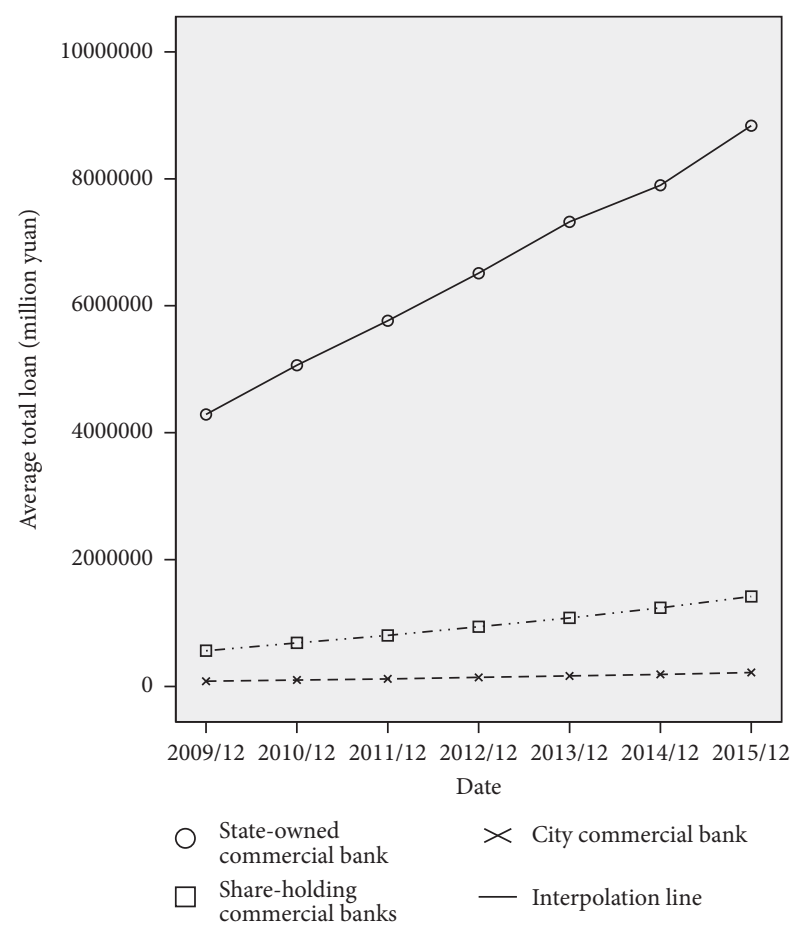

FIgURE 1: The HHI chart of the average concentration risk of sample bank loans.

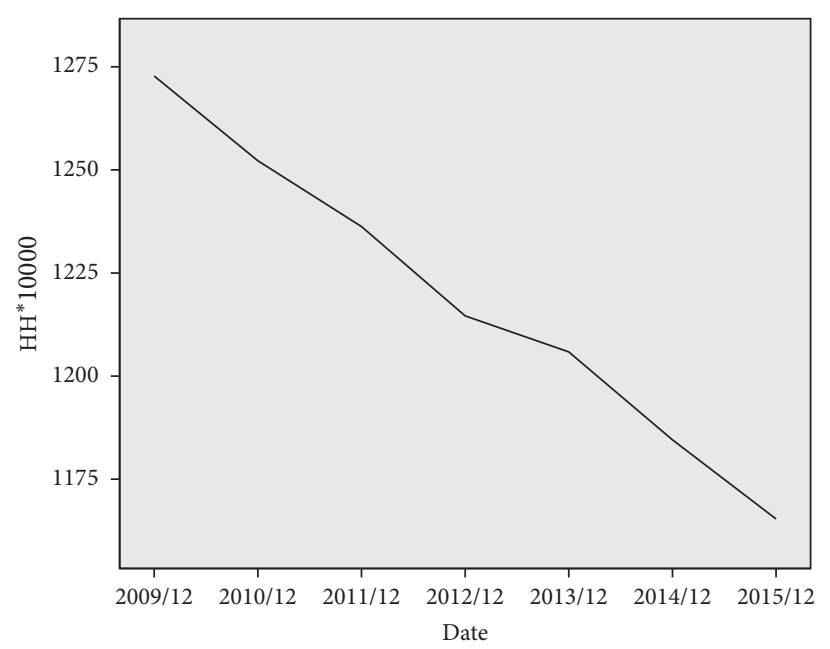

FIgURE 2: The HHI of China banking industry total loan concentration risk.

banks' annual loans accounted for 13.1\%-19.96\%. Except for the Bank of Communications, all other banks account for less than $5 \%$. The cumulative total of other banks accounted for $25.89-31.29 \%$.

This paper calculates the manufacturing credit loan $\mathrm{HHI}$ based on the total manufacturing loan data of the above 25 commercial banks from December 2008 to December 2015 and draws a line chart of manufacturing credit concentration risk (Figure 5).

From Figure 5, the concentration risk of the total credit loans of the sample bank manufacturing industry changes within the range of 1097-1247. It shows that the 


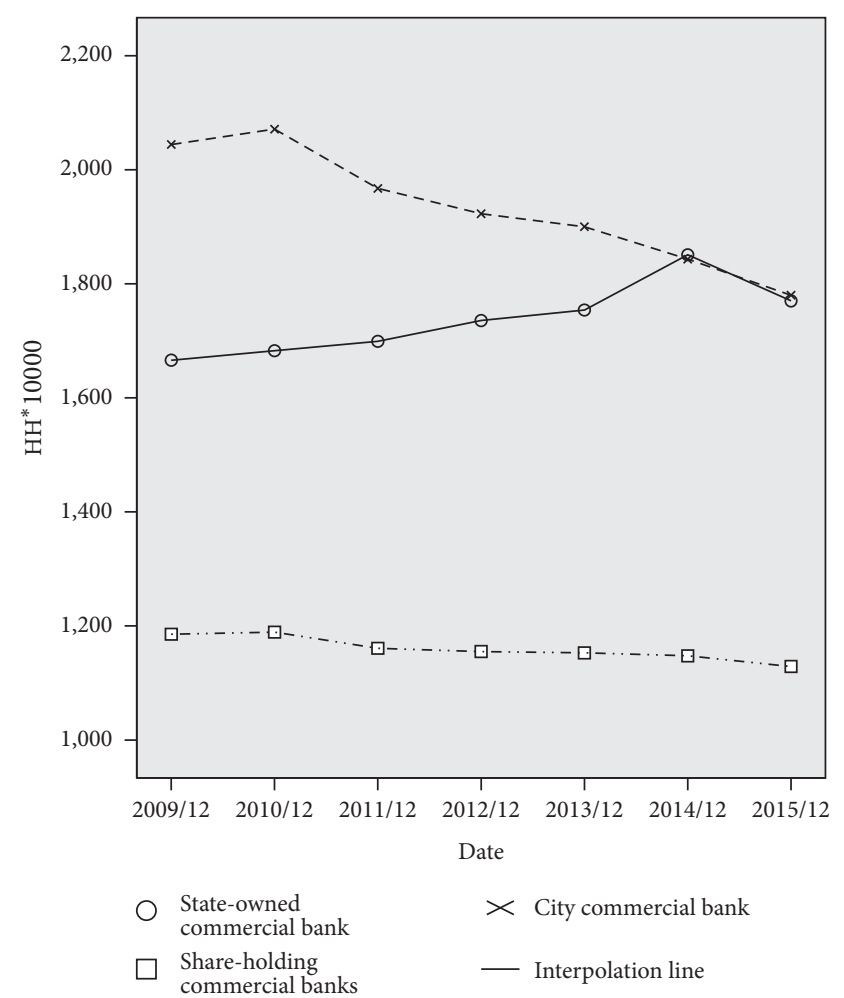

FIGURE 3: Line chart of HHI of total bank loan risk of various types.

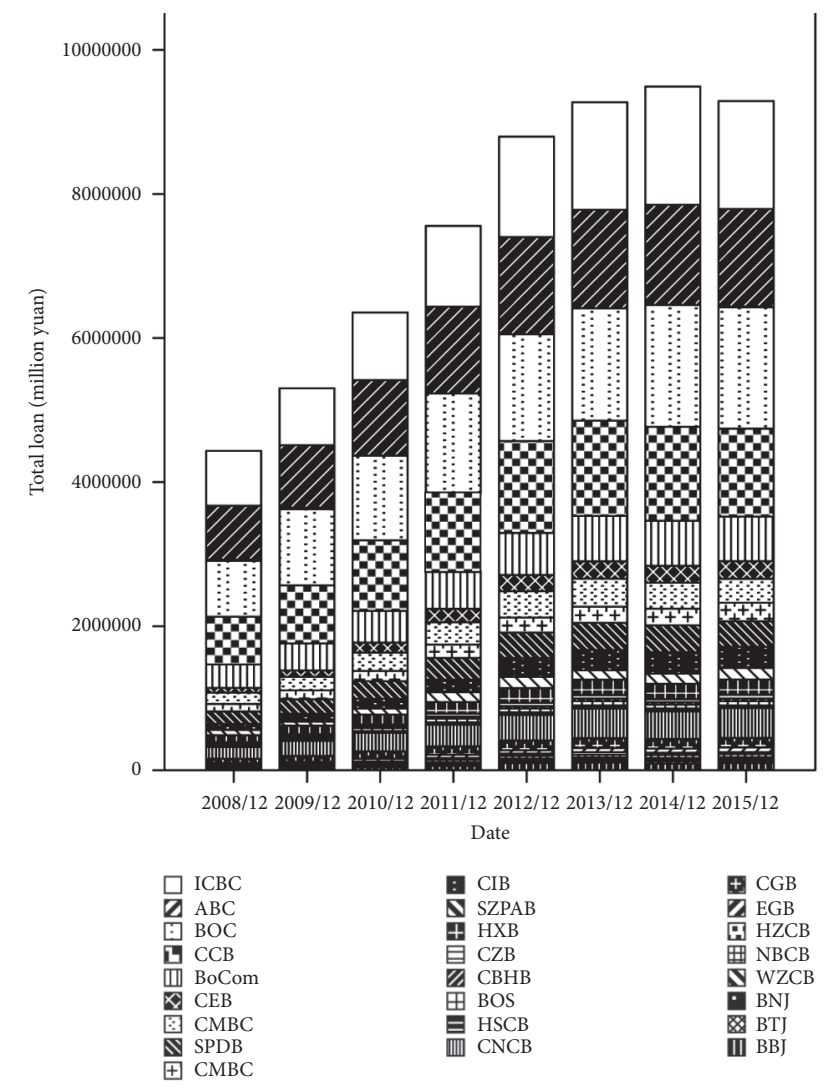

FIgURE 4: Accumulated distribution map of total manufacturing loans of sample banks.
TABle 2: Proportion of loans from state-owned commercial banks in the manufacturing industry over the years.

\begin{tabular}{lcccccc}
\hline $\begin{array}{l}\text { The proportion } \\
(\%)\end{array}$ & ICBC & ABC & BOC & CCB & BoCom & $\begin{array}{l}\text { Other } \\
\text { banks }\end{array}$ \\
\hline Dec 2008 & 17.12 & 17.22 & 17.56 & 14.97 & 7.25 & 25.89 \\
Dec 2009 & 14.95 & 16.71 & 19.96 & 15.14 & 7.14 & 26.09 \\
Dec 2010 & 14.80 & 16.47 & 18.51 & 15.40 & 6.90 & 27.92 \\
Dec 2011 & 14.84 & 15.93 & 18.25 & 14.54 & 6.78 & 29.65 \\
Dec 2012 & 15.83 & 15.35 & 16.86 & 14.50 & 6.64 & 30.83 \\
Dec 2013 & 16.05 & 14.80 & 16.79 & 14.26 & 6.80 & 31.29 \\
Dec 2014 & 17.30 & 14.66 & 17.81 & 13.75 & 6.58 & 29.90 \\
Dec 2015 & 16.11 & 14.72 & 18.13 & 13.10 & 6.70 & 31.25 \\
\hline
\end{tabular}

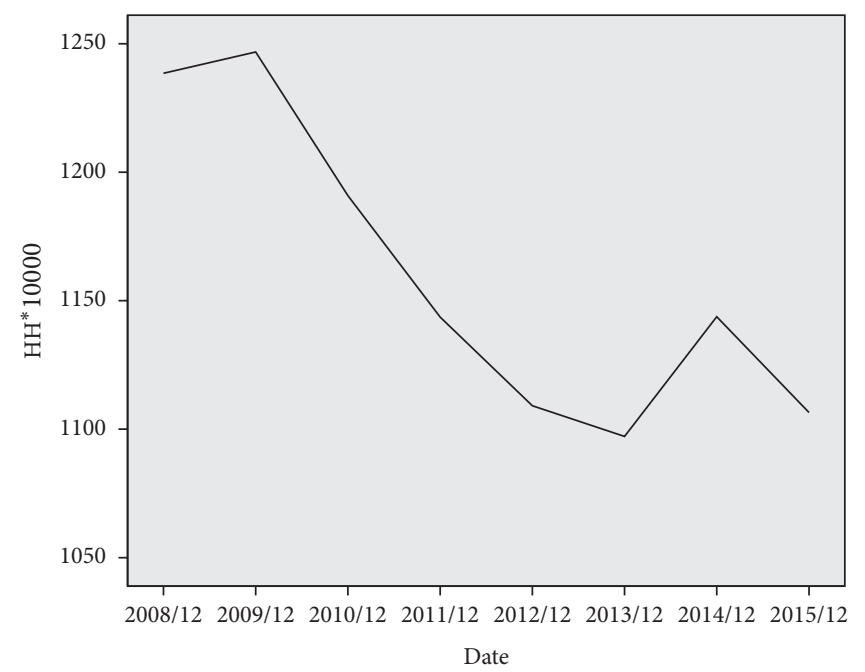

FIgURE 5: Line chart of manufacturing credit HHI.

manufacturing credit structure is in the low-oligarch II range. In other words, the manufacturing credit concentration risk is consistent with the overall risk of China's banking industry and is in a lower risk area. This structure distribution has a clear downward trend from 2009 to 2013, with the lowest value in 2013 and the highest value in 2009, and there was a noticeable volatility in 2014. This change not only is due to changes in bank credit behavior but also related to the decline in Chinese corporate credit demand. During the transformation and upgrading of the real economy and the period of innovation-driven adjustment, the manufacturing industry was the most affected.

\section{Measuring the Lerner Index of Banking Credit Concentration Risk}

The Lerner Index is a commonly used indicator to measure the degree of market competition in the industry and is also used to measure the market concentration of the industry. Shaffer first applied this method to the banking industry. The results using industry time series data show that the US and Canadian banks are in a state of perfect competition. Compared with the $\mathrm{HHI}$ in the previous section, the Lerner index is not as common as the HHI because of the complexity of the calculation and the difficulty of data acqui- 
sition. However, because the theoretical background of its new industrial organization is more in line with today's market environment, and it is different from the dynamic measurement angle of the HHI, this article selects this index to compare with the analysis results of the above HHI.

3.1. Description of Data. This article selects 12 banks as samples, namely, Industrial and Commercial Bank of China, Agricultural Bank of China, Bank of China, China Construction Bank, Bank of Communications, China CITIC Bank, China Merchants Bank, Hua Xia Bank, China Everbright Bank, Industrial Bank, Pudong Development Bank, and Guangdong Development Bank. The sample period is from 2008 to 2015 . The definition of each variable is shown in Table 3.

\subsection{Theoretical Framework and Econometric Model.} Suppose that bank $i$ is a manufacturer pursuing profit maximization, and loans are its only output. Deposit interest expenses of depositors and employees' salary expenses are the two production factors that banks must invest. The economic environment portrayed in this article is as follows. In the credit loan market, there are $n$ banks that can provide homogeneous loans and compete with Cournot for lenders. At this time, the inverse demand function of bank $i$ in the credit market of the region is $p=p(Q, z)$, where $p$ represents the loan interest rate of the bank and $Q$ is the total loan provided by $n$ banks in the regional loan market, that is, $Q=\sum_{i=1}^{n} q_{i}$, where $q_{i}$ is the total credit of bank $i$ and $z$ is other exogenous variables that affect the borrower's loan demand.

Let $C\left(q_{i}, \omega_{i}\right)$ be the cost function of bank $i$ credit, where $\omega_{i}$ is the price vector of bank $i$ input factors. Therefore, the optimization problem of bank $i$ is

$$
\max _{q_{i}} \pi_{i}=p(Q, z) q_{i}-C\left(q_{i}, \omega_{i}\right) .
$$

The first-order conditions should be

$$
\frac{\partial \pi}{\partial q_{i}}=p+q_{i} \frac{\partial p}{\partial Q} \frac{\partial Q}{\partial q_{i}}-\frac{\partial C_{i}}{\partial q_{i}}=0 .
$$

Let $m c_{i}$ be the marginal cost of bank $i, m c_{i}=\partial C_{i} / \partial q_{i}$. Definition $\eta=-(\partial Q / \partial p)(1 / Q)$ is the semielasticity of loan demand to loan interest rate, $\theta_{i}=-\left(\partial Q / \partial q_{i}\right)\left(q_{i} / Q\right)$ is the total loan supply quantity $Q$ and the estimated elasticity of the loan supply quantity $q_{i}$ of bank $i$. Equation (4) can be written as follows:

$$
p=m c_{i}+\frac{\theta_{i}}{\eta}
$$

The monopoly pricing according to Appelbaum only

\begin{tabular}{|c|c|c|}
\hline Variable & Meaning & Definition of this article \\
\hline$C_{i t}$ & Total cost & aterest expenses + operating expenses \\
\hline$q_{i t}$ & Loan output & ans \\
\hline$R_{i t}$ & $\begin{array}{l}\text { Interest } \\
\text { income }\end{array}$ & Loan interest income \\
\hline$\omega_{1 i t}$ & Lending rates & Interest expense/ \\
\hline$\omega_{2 i t}$ & Wage rate & $\begin{array}{c}\text { Operating expenses/number of } \\
\text { employees }\end{array}$ \\
\hline$p_{i t}$ & Lending rates & $\begin{array}{c}\text { Interest income/total interest-earning } \\
\text { assets }\end{array}$ \\
\hline $\mathrm{npl}_{i t}$ & NPL ratio & Loan loss provision/total loan \\
\hline
\end{tabular}
needs to estimate $\theta_{i} / \eta$. Definition $\lambda_{i}=\theta_{i} / \eta$; it is derived from
TABLE 3: Definition of variables.

equation (5): $\lambda_{i}=p-m c_{i} \cdot L_{i}$ is used to represent the Lerner Index. According to its definition $L_{i}=p-m c_{i} / p=$ $\lambda_{i} / p, L_{i} \in[0,1]$, the index is used to measure the deviation of price from marginal cost.

Then, multiply both ends of equation (5) by $q_{i}$ at the same time, we can obtain

$$
R_{i}=p q_{i}=m c_{i} q_{i}+\frac{\theta_{i}}{\eta} q_{i}=m c_{i} q_{i}+\lambda_{i} q_{i} .
$$

In the equation, $R_{i}$ represents the interest income of bank $i . m c_{i}$ cannot be directly observed; this article sets the cost function as a superlogarithmic cost function for this purpose:

$$
\begin{aligned}
\ln C_{i}= & \alpha_{0}+\alpha_{1} \ln q_{i}+\frac{\alpha_{2}}{2}\left(\ln q_{i}\right)^{2}+\sum_{k=1}^{2} \beta_{k} \ln \omega_{k i} \\
& +\sum_{k=1}^{2} \gamma_{k} \ln q_{i} \ln \omega_{k i}+\frac{1}{2} \sum_{k=1}^{2} \varphi_{k k}\left(\ln \omega_{k i}\right)^{2} \\
& +\varphi_{12} \ln \omega_{1 i} \ln \omega_{2 i} .
\end{aligned}
$$

In the equation, $C_{i}$ represents the total cost of bank $i, q_{i}$ is the total loan supply of bank $i$, and $\omega_{1 i}$ and $\omega_{2 i}$ represent the deposit interest rate and wage rate of exogenous variables, respectively. It follows that the marginal cost of bank $i$ is

$$
m c_{i}=\frac{\partial C_{i}}{\partial q_{i}}=\frac{C_{i}}{q_{i}}\left[\alpha_{1}+\alpha_{2} \ln q_{i}+\sum_{k=1}^{2} \gamma_{k} \ln \omega_{k i}\right] .
$$

Substituting equation (8) into equation (6), this paper obtains

$$
R_{i}=C_{i}\left[\alpha_{1}+\alpha_{2} \ln q_{i}+\sum_{k=1}^{2} \gamma_{k} \ln \omega_{k i}\right]+\lambda_{i} q_{i} .
$$

Then, convert equations (7) and (9) into panel data form to establish simultaneous equations: 


$$
\begin{aligned}
\ln C_{i}= & \alpha_{0}+\alpha_{1} \ln q_{i}+\frac{\alpha_{2}}{2}\left(\ln q_{i t}\right)^{2}+\sum_{k=1}^{2} \beta_{k} \ln \omega_{k i} \\
& +\sum_{k=1}^{2} \gamma_{k} \ln q_{i t} \ln \omega_{k i t} \\
& +\frac{1}{2} \sum_{k=1}^{2} \varphi_{k k}\left(\ln \omega_{k i t}\right)^{2}+\varphi_{12} \ln \omega_{1 i t} \ln \omega_{2 i t} \\
& +\rho \ln \operatorname{npl}_{i t}+\sum_{j=2}^{14} \delta_{j} \mathrm{bank}_{j}+\varepsilon_{i t}, \\
R_{i t}= & C_{i t}\left[\alpha_{1}+\alpha_{2} \ln q_{i t}+\sum_{k=1}^{2} \gamma_{k} \ln \omega_{k i t}\right]+\lambda_{i} q_{i t}+v_{i t} .
\end{aligned}
$$

Among them, $t=2008,2009, \ldots, 2015$, is the sample time period. In equation (10), $\mathrm{npl}_{i t}$ represents the nonperforming loan rate of the bank, and a dummy variable representing different banks is also added. Simultaneously estimating (10) and (11) the two equations to obtain the bonus $\lambda$ throughout the sample period. In order to get the annual bonus during the sample period, equation (11) is rewritten as follows:

$$
\begin{aligned}
R_{i t}= & C_{i t}\left[\alpha_{1}+\alpha_{2} \ln q_{i t}+\sum_{k=1}^{2} \gamma_{k} \ln \omega_{k i t}\right] \\
& +\sum_{s=2005}^{2014} \lambda_{s} \operatorname{dum}_{s} q_{i t}+v_{i t} .
\end{aligned}
$$

Among them, $\operatorname{dum}_{s}$ is a dummy variable. When $s=t$, $\operatorname{dum}_{s}$ takes the value 1 , otherwise it is 0 . This paper estimates that the simultaneous equations composed (10) and (12) will benefit each year's bonus, that is, $\lambda_{s}$ is the coefficient to be emphasized in this paper. Divide its estimated value $p_{t}$ by the average loan interest rate of the same year, that is, calculate the Lerner Index used to measure the degree of market competition of the bank in the sample period, thereby determining the concentration risk.

According to the manufacturer's theoretical requirements, a good-quality cost equation needs to meet certain properties. One-time homogeneousness of factor prices requires the coefficients of the superlogarithmic production function to satisfy the following constraints:

$$
\begin{aligned}
\beta_{1}+\beta_{2} & =1, \\
\gamma_{1}+\gamma_{2} & =0, \\
\varphi_{11}+\varphi_{12} & =\varphi_{22}+\varphi_{12}=\varphi_{11}+\varphi_{22}+2 \varphi_{12}=0 .
\end{aligned}
$$

When estimating, $\beta_{1}=1-\beta_{2}, \gamma_{2}=-\gamma_{1}, \varphi_{11}=\varphi_{22}$, and $\varphi_{12}=-\varphi_{11}$ can be directly substituted into the system of equations, which is called constrained estimation. Correspondingly, estimates without constraints (13), (14) and (15) are called unconstrained estimates. In this paper, the results of these two estimates are compared to determine the value range of the results.

3.3. Empirical Results and Interpretation. As the nonperforming loan rate itself is a lagging variable of credit quality, there will be a certain time lag before new loans become nonperforming loans, and it will further show the trend of the nonperforming loan rate with the trend of economic growth. Therefore, in the establishment of the model in this paper, the one-stage lag variables of $C_{i t}$ and $q_{i t}$ are used as its instrument variables, using Eviews software and using three-stage least squares (3SLs) to estimate. Due to the use of hysteresis variables, this article derives the estimated value of $\lambda_{2008}, \lambda_{2009}, \ldots, \lambda_{2014}, \lambda_{2015}$. After using the data of all banks for estimation, this paper divides all the data into two groups of data of the four major state-owned commercial banks and joint-stock commercial banks and then performs the same estimation (Table 4).

In the unconstrained estimation of all banks in this paper, the equation fit is high, but the variables are basically insignificant, indicating that there is multiple collinearity between the variables of the unconstrained model. In contrast, all variables with constrained estimates are significant. After the special addition $k(k=2008,2009, \ldots$, 2015), the difference between the unconstrained estimate and the constrained estimate is very small, but all $a$ in the constrained estimate are significant. State-owned banks and joint-stock banks estimate the same. Taking constraints (13), (14) and (15) as the original hypothesis, the F-test is performed to determine whether the production function meets the factor price once homogeneity hypothesis. The results show that the original hypothesis cannot be rejected. So far, this paper believes that the model satisfies constraints (13), (14) and (15) and uses the results of constrained estimation. Table 4 shows that, for all banks and joint-stock banks, the NPL ratio has a significant impact on the total cost of the bank which is significantly positive, indicating that after controlling for other variables, and the increase in the NPL ratio will significantly increase the total cost of the bank.

According to the definition, the average interest rate and marginal cost of loans of the sample banks in each year are further obtained to calculate the bank's Lerner Index. The estimated values of the banks are shown in Table 5 .

This paper draws a line chart of the average loan interest rate and marginal cost of the three types of sample banks (Figures 6 and 7). The average loan interest rate line chart shows that the loan interest rates of the three types of sample banks have risen rapidly since 2008, peaked in 2011, and then fell rapidly. The marginal cost line chart shows a similar 
TABLE 4: Estimated results.

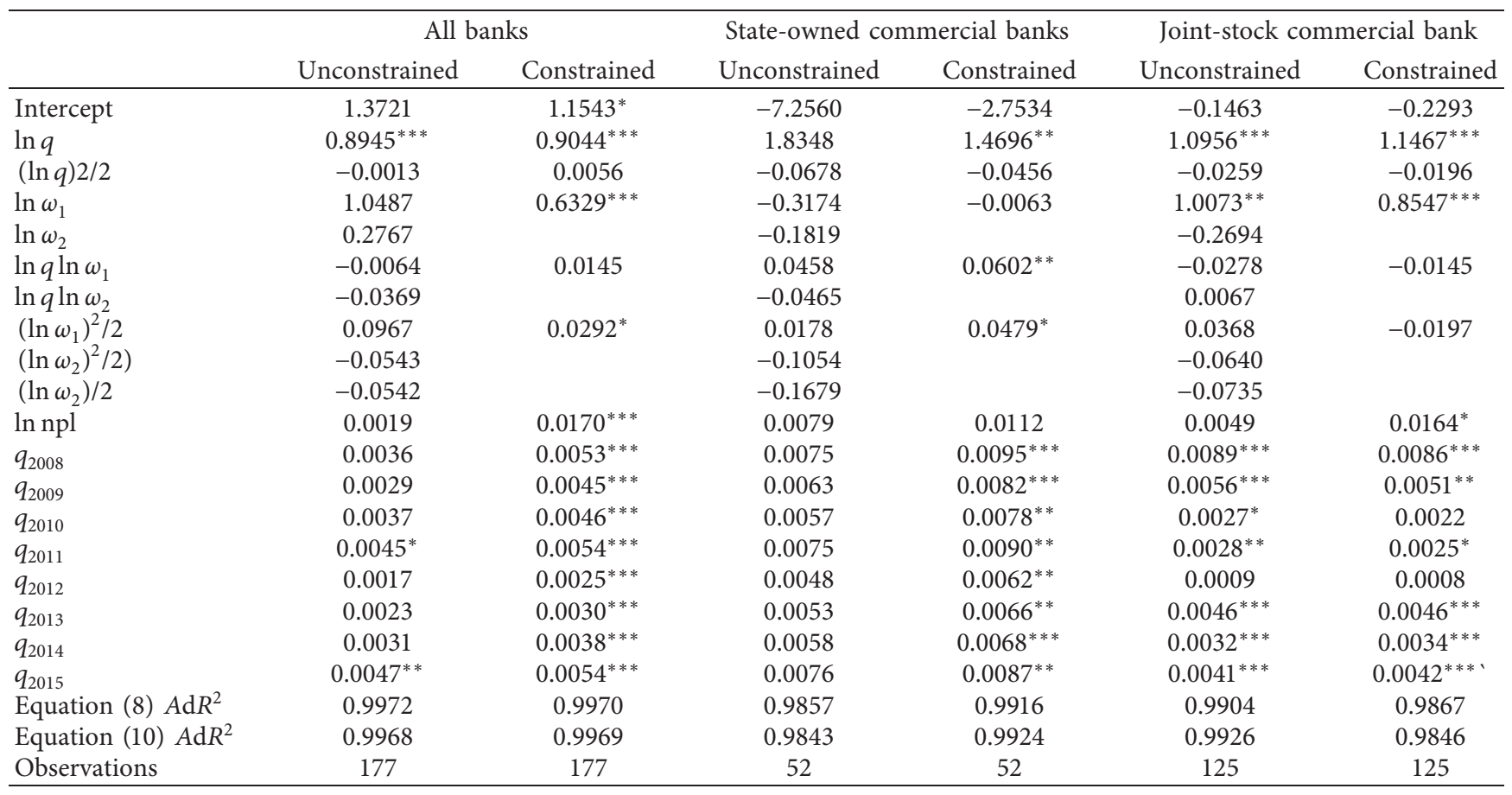

Note. ${ }^{* * *},{ }^{* *}$, and ${ }^{*}$ indicate that they are significant at the levels of $1 \%, 5 \%$, and $10 \%$, respectively; due to space limitations, the estimation results of dummy variables representing banks are not given here.

TABle 5: Estimated values.

\begin{tabular}{cccccccccc}
\hline \multirow{2}{*}{ Year } & \multicolumn{3}{c}{ Average loan interest rate } & \multicolumn{3}{c}{ Marginal cost of loan } & \multicolumn{2}{c}{ Lerner Index } \\
& All & State-owned & Share-holding & All & State-owned & Share-holding & All & State-owned & Share-holding \\
\hline 2008 & 0.0545 & 0.0542 & 0.0547 & 0.0468 & 0.0456 & 0.0481 & 0.3585 & 0.3529 & 0.3666 \\
2009 & 0.0567 & 0.0563 & 0.0576 & 0.0503 & 0.0458 & 0.0548 & 0.3513 & 0.3460 \\
2010 & 0.0593 & 0.0587 & 0.0596 & 0.0474 & 0.0458 & 0.0489 & 0.4122 & 0.4097 & 0.3547 \\
2011 & 0.0665 & 0.0664 & 0.0673 & 0.0600 & 0.0625 & 0.0575 & 0.3750 & 0.3692 & 0.3816 \\
2012 & 0.0614 & 0.0606 & 0.0615 & 0.0444 & 0.0445 & 0.0442 & 0.3578 & 0.3577 \\
2013 & 0.0602 & 0.0597 & 0.0610 & 0.0564 & 0.0557 & 0.0572 & 0.3502 & 0.3488 & 0.3627 \\
2014 & 0.0587 & 0.0579 & 0.0591 & 0.0477 & 0.0440 & 0.0514 & 0.3487 & 0.3452 & 0.3575 \\
2015 & 0.0462 & 0.0457 & 0.0465 & 0.0334 & 0.0398 & 0.0270 & 0.3575 & 0.3542 & 0.3606 \\
\hline
\end{tabular}

situation, but with more fluctuations than the average loan interest rate.

From Figure 8, the sample bank's Lerner Index fluctuated between 2008 and 2015. It fell back slightly from 2008 to 2009 , reached a peak of 0.4122 in 2010, and then fell back to around 0.35 , slightly rising in 2015. Among them, the Lerner Index of state-owned banks is slightly lower than that of all banks, and joint-stock banks are slightly higher than all banks during the same period.

In order to better compare the difference between the banking industry concentration risk $\mathrm{HHI}$ and the Lerner
Index measurement, this article compares the HHI of all banks in 2008-2015 and the Lerner Index of all banks (stateowned and share-holding commercial) in the same time period.

As can be seen from Figure 9, the changes in the HHI and the Lerner Index are not consistent. From 2008 to 2010 and from 2013 to 2015, the opposite trend has appeared. Because $\mathrm{HHI}$ and Lerner Index are more commonly used and Lerner Index has some idealized processing in the calculation process, this paper believes that HHI calculation results are more reliable. 


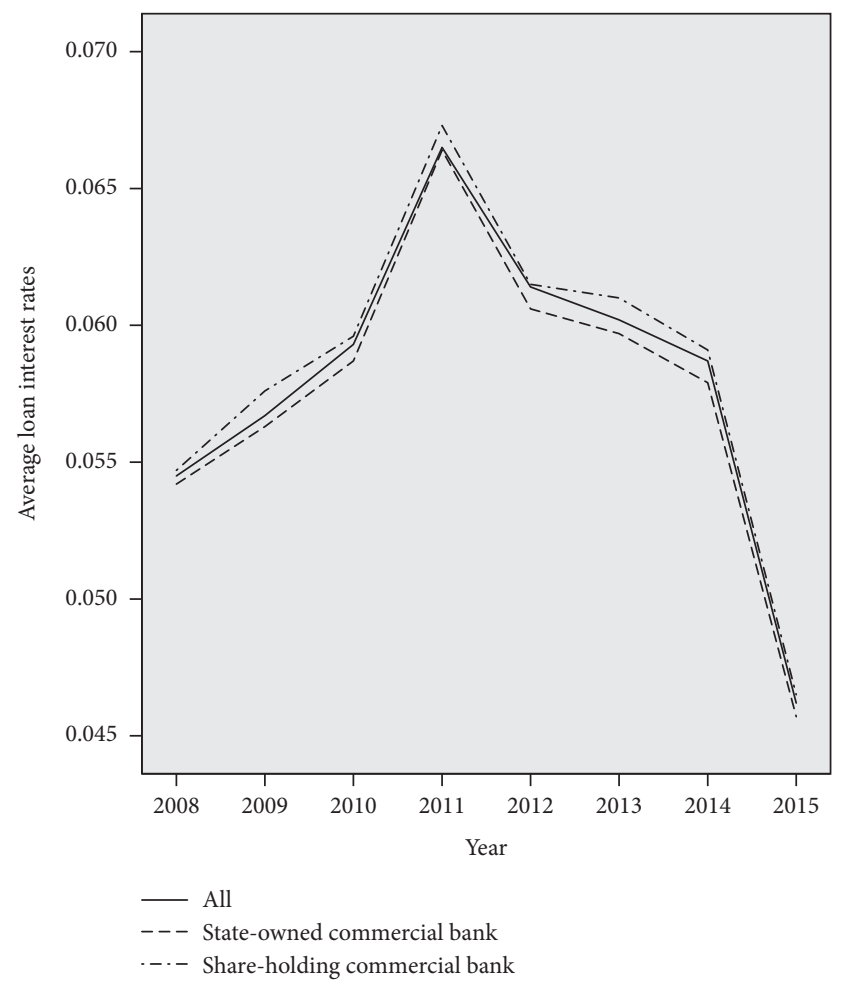

FIGURE 6: Line chart of average loan interest rates of various banks.

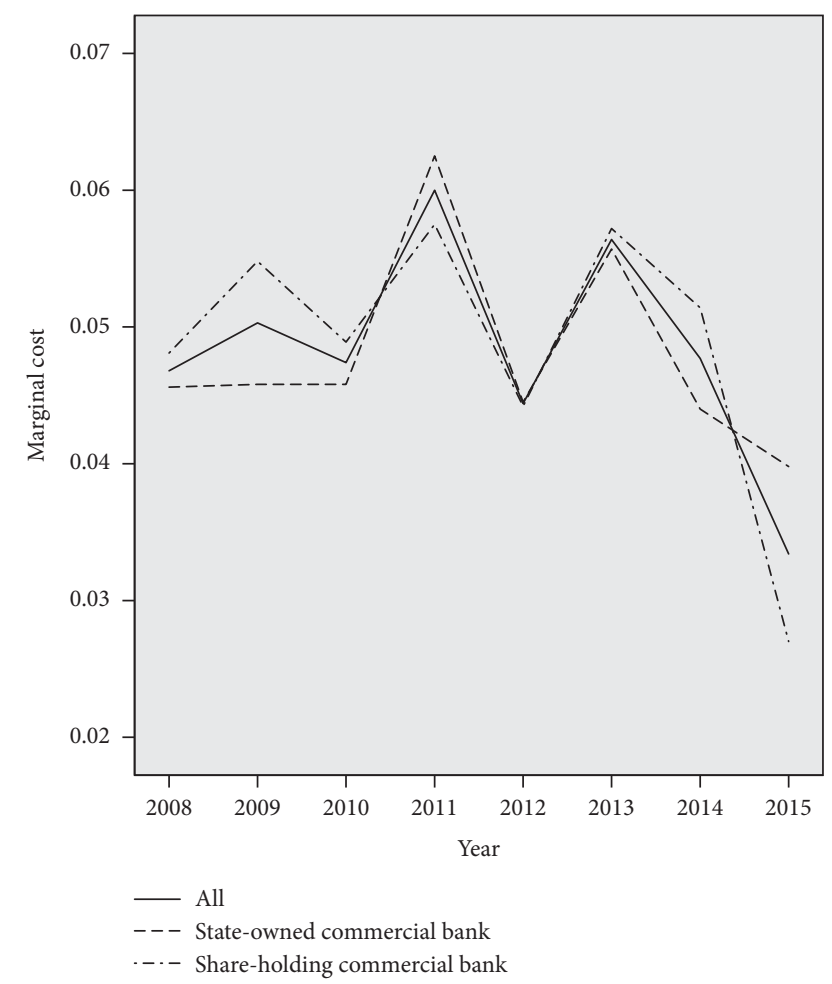

FIgURE 7: Line chart of marginal cost of various bank loans.

\section{Conclusion}

This paper calculates the HHI of the Chinese banking industry according to the three types of state-owned banks,

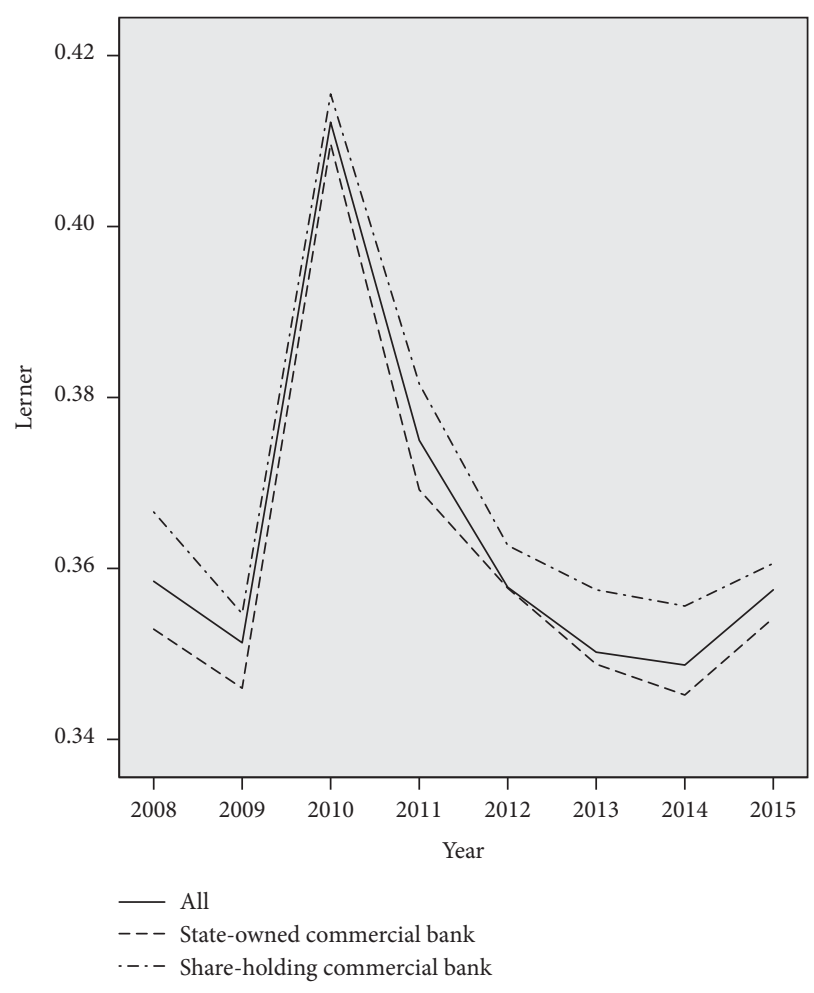

FIGURE 8: Line chart of the Lerner Index of bank concentration risk.

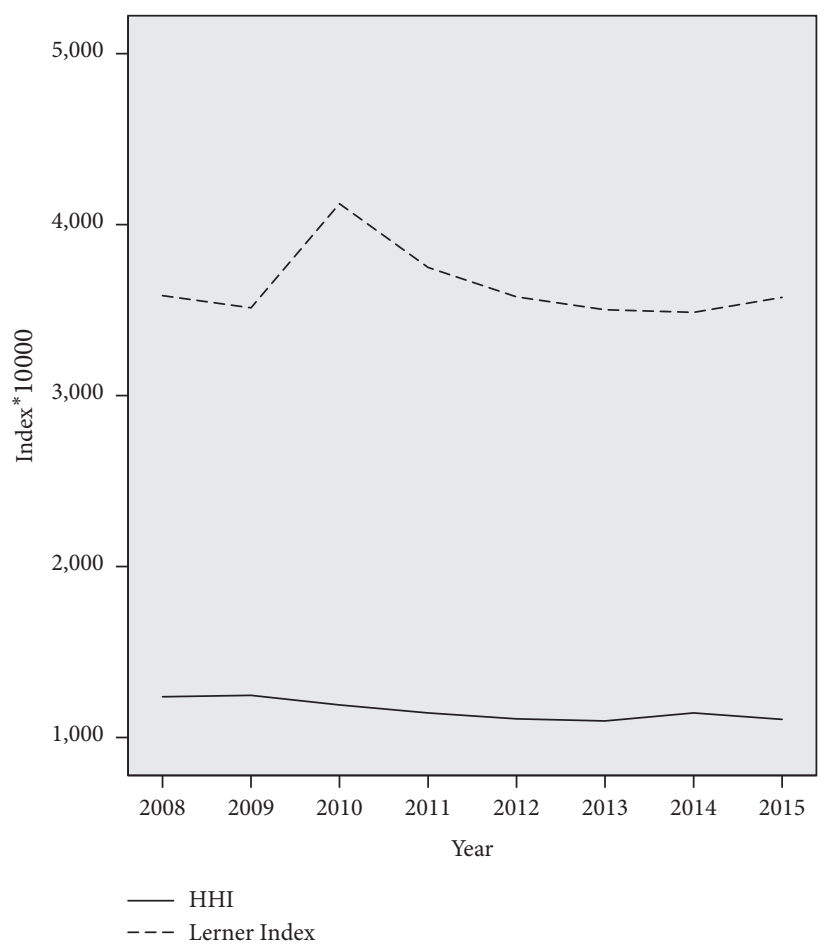

Figure 9: Comparison of HHI and Lerner Index.

joint-stock banks, and city banks from the average credit and industry credit, respectively, and derives the difference in the credit risk concentration of commercial banks of various types. Banks are in the middle, and joint-stock banks are the 
lowest. Judging from the overall measurement data, the credit risk of China's banking industry is at a low level and has a further downward trend. The Lerner Index of the measured sample banks fluctuated between 2008 and 2015, but after 2014, the banking industry's competitiveness declined rapidly, concentration risk rose rapidly, and the concentration risk trends of banks of various natures were similar.

\section{Data Availability}

The data used to support the findings of this study are available from the corresponding author upon request.

\section{Conflicts of Interest}

The authors declare that there are no conflicts of interest regarding the publication of this paper.

\section{References}

[1] J. C. Panzar and J. N. Rosse, "Testing for "monopoly" equilibrium," The Journal of Industrial Economics, vol. 35, no. 4, pp. 443-456, 1987.

[2] J. C. Panzar and J. N. Rosse, Structure Conduct and Comparative Statistics, Bell Labs, Murray Hills, NJ, USA, 1982.

[3] T. F. Bresnahan, "The oligopoly solution concept is identified," Economics Letters, vol. 10, no. 1-2, pp. 87-92, 1982.

[4] L. J. Lau, "On identifying the degree of competitiveness from industry price and output data," Economics Letters, vol. 10, no. 1-2, pp. 93-99, 1982.

[5] S. Shaffer, "A test of competition in Canadian banking," Journal of Money, Credit and Banking, vol. 25, no. 1, pp. 49-61, 1993.

[6] P. Angelini and N. Cetorelli, "The effects of regulatory reform on competition in the banking industry," Journal of Money, Credit, and Banking, vol. 35, no. 5, pp. 663-684, 2003.

[7] T. Yang and Y. Zhong, "The concentration, competition and bank risk of China's banking industry," Financial Research, vol. 1, pp. 122-134, 2013.

[8] T. F. Hellmann, K. C. Murdock, and J. E. Stiglitz, "Liberalization, moral hazard in banking, and prudential regulation: are capital requirements enough?" American Economic Review, vol. 90, no. 1, pp. 147-165, 2000. 